\title{
Analysis of Knowledge and Management of Dysmenorrhea in Students Before and After the Application of Leaflets and Flipcharts
}

\author{
$1^{\text {st }}$ Sri Susanti \\ Midwifery Study Program \\ Politeknik Kesehatan Aisyiyah Banten \\ Serang, Banten, Indonesia \\ santi@poltekkes-aisyiyahbanten.ac.id
}

\author{
$2^{\text {nd }}$ Ika Apriyanti \\ Midwifery Study Program \\ Politeknik Kesehatan Aisyiyah Banten \\ Serang, Banten, Indonesia
}

\author{
$3^{\text {rd }}$ Lina Marliana \\ Midwifery Study Program \\ Politeknik Kesehatan Aisyiyah Banten \\ Serang, Banten, Indonesia
}

\begin{abstract}
Menstruation as vaginal bleeding that occurs periodically due to the release of the uterine mucosa. The menstrual cycle begins with menarche and will continue until menopause around the age of $45-55$ years (Helen, 2010). Studies of systematic reviews in developing countries find that $25-50 \%$ of adult women and around $75 \%$ of adolescents experience painful sensations during menstruation, with five to twenty percent reported experiencing dysmenorrhea severeor inhibiting them in their daily activities (Harlow, 2004). This study aims to try to give treatment to a counseling model by using leaflet and flipchart media then analyze the level of change before and after the model is applied in Anyer High School and the results of this study are expected to be used as a reference for health, dysmenorrhea especially for students who are still called the juvenile category to improve coping patterns when menstruation is coming The research method used was to use a survey method, which is a research design that provides both quantitative and numerical descriptions. Sampling using purposive random sampling of 420 students. The results of the study were analyzed in stages through univariate and bivariate analysis. The results showed that the average value of knowledge change using flip media (77.98) was greater than the media leaflet (77.48). The results of the analysis of the method leaflet and flipchart with the Wilcoxon Test obtained p-value $=0,000$, which means that both media influence increasing knowledge about dysmenorrhea students in SMA Negeri 1. It was concluded that the method leaflet and the flipchart method both had effects on the score of student knowledge about menstrual pain (dysmenorrhea).
\end{abstract}

Keywords—Dysmenorrhea, Leaflets, Flipcharts

\section{INTRODUCTION}

Menstruation as vaginal bleeding that occurs periodically due to the release of the uterine mucosa. The menstrual cycle begins with menarche and will continue until menopause around the age of 45-55 years [1].

Most people still consider talking about menstruation a taboo, whereas menstruation is a normal condition experienced by all women. Like maintaining general hygiene, managing menstrual hygiene also involves many parties, especially when it comes to matters of public sanitation. Adult women may have a better understanding of maintaining menstrual health in public areas, but the problem is young women who are still at school age. They tend to have problems to maintain menstrual hygiene at school. Managing menstrual hygiene is an effort to create conditions where women and young women have the right knowledge and a clean and healthy lifestyle during menstruation, such as using sanitary pads (disposable or cloth pads) that can be replaced as often as possible during menstruation. sexual problems but also involves all aspects of reproduction, especially for young women who later become a woman responsible for their offspring. Teenage girls experience menstruation sometimes experience pain during menstruation or menstruation, this disease is only experienced by women. This disease is called dysmenorrhea or menstrual pain [2].

Complaints that are felt by many girls when menstruation is a pain in the stomach which is commonly called dysmenorrhea, this pain resembles a spasm and occurs in the lower abdomen. This pain is roughly a kind of pain that arises when our hands are tied tightly. Handling and reducing pain at the time of dysmenorrhea until now there are still many who do not know, mostly by administering pain-reducing medication alone. Based on a preliminary study of young women in SMAN I grade XI totaling 25 people, obtained as many as 20 female students (80\%) had dysmenorrhea and 5 young women students $(20 \%)$ did not have dysmenorrhea. Among 5 adolescent girls who did not experience dysmenorrhea it was found 1 (20\%) of adolescent girls who had not gotten menstruation. Then from 20 young women, 15 students $(75 \%)$ did not know about menstrual pain and 5 young women $(25 \%)$ knew about menstrual pain. Among the 20 young women who experience pain during menstruation 10 young women $(50 \%)$ overcome their pain by taking drugs without a doctor's prescription and 10 young women $(50 \%)$ are left alone without treatment.

Therefore, the knowledge of young women about menstrual pain (dysmenorrhea) is important to observe because there are still many young women who do not know about it and one of the counseling media that can be used is by leaflets and leaflets about dysmenorrhea. Indeed, this model has been used by the government to the community, but the government only concentrates on the community in the villages only, not touching the students in the school in his village, therefore hopefully this effort will be one of the solutions to help the government in reaching other communities for his health program. 


\section{METHODS}

The research method used is to use a survey method, which is a research design that provides quantitative or numerical descriptions. Sampling using purposive random sampling of 420 students. The results of the study were analyzed in stages through univariate and bivariate analysis [3].

\section{RESULTS AND DISCUSSION}

\section{A. Univariate Analysis}

TABLE 1. THE NUMBER OF GRADE XI STUDENTS SUBJECTED TO RESEARCH BASED ON TREATMENT AT SMAN 1 ANYER, ANYER DISTRICT, SERANG REGENCY, BANTEN PROVINCE, INDONESIA, 2019

\begin{tabular}{|c|c|c|}
\hline Group & $\mathrm{n}$ & $\mathbf{\%}$ \\
\hline Leaflet & 210 & 50 \\
\hline Sheets Feedback & 210 & 50 \\
\hline Total & 420 & 100 \\
\hline
\end{tabular}

Based on the table 1, the number of obtained students who were the subjects in this study were 420 respondents. Based on the media group leaflet, 210 respondents $(50 \%)$ were obtained and the flip group was 210 respondents $(50 \%)$.

TABLE 2. VALUES OF NUMBER OF STUDENTS, MEAN AND STANDARD DEVIATION (SD) OF PRETEST, POSTTEST, AND EFFECT BASED ON TREATMENT AND TOTAL IN SMAN 1ANYER, ANYER DISTRICT, SERANG REGENCY, BANTEN PROVINCE, INDONESIA, 2019

\begin{tabular}{|l|c|c|c|c|}
\hline \multicolumn{1}{|c|}{ Variable } & Mean & SD & Min & Max \\
\hline & & & & \\
\hline Pretest Leaflet & 71.94 & 8.03 & 40.00 & 90.00 \\
\hline Posttest Leaflet & 77.48 & 4.77 & 66.00 & 93.00 \\
\hline Pretest-Feedback Sheet & 71.99 & 7.96 & 40.00 & 90.00 \\
\hline Posttest-Feedback Sheet & 77.98 & $5: 31$ & 50.00 & 95.00 \\
\hline
\end{tabular}

Based on the results, the mean of the leaflet is 71.94 pretest, posttest leaflet $77.48,71.99$ behind the sheet pretest, posttest flipchart 77.98. The standard deviation (SD) of the pretest leaflet is 8.03 posttest leaflet 4.77, the flipchart pretest is 7.96 , the post-test is turning sheet 5.31. The lowest value of the pretest leaflet is 40.00 , posttest leaflet 66.00 , pretest Flip sheet 40.00, posttest flip sheet 50.00 The highest value of pretest leaflet is 90.00 posttest leaflet 93.00 , pretest flip sheet 90.00 posttest flipchart 95.00 .

\section{B. Bivariate Analysis Bivariate}

TABLE 3. TEST PRETEST WITH POSTTEST IN THE GROUP LEAFLET

\begin{tabular}{|c|c|}
\hline Variable & P-value \\
\hline & \\
\hline Pre-test Leaflet & 0,000 \\
\cline { 1 - 1 } Post-test Leaflet & \\
\hline
\end{tabular}

Based on table 3 by using Wilcoxon test, shows that the pre-test leaflet value with the post-test leaflet value has a value of $\mathrm{p}=0,000(<0.05)$ which means there is a significant difference between the value of pretest leaflets and values post-test leaflet.

The results of this research have higher results than the research conducted by Khoiron (2014) in the Work Area Kartasura Sukoharjo Health Center (PUSKESMAS) which shows the average pretest value of respondent's knowledge by using a leaflet of 12.00 the average posttest value increased to 14,37 , resulting in an increase in the average value of respondents by 2.37 . This is also supported by Kawuriansari's research (2010) in 01 Christian Middle School Purwokerto Banyumas Regency which shows that knowledge is better after receiving treatment/information exposure with media leaflets. The results of the analysis showed that this study obtained $\mathrm{p}$-value $=0,000$, which means that the media leaflet affects the score of respondent's knowledge about dysmenorrhea.

TABLE 4. TEST BIVARIATE BETWEEN PRETEST TO POSTTEST GROUP FEEDBACK SHEET

\begin{tabular}{|c|c|}
\hline Variable & P-value \\
\hline Pretest-Feedback Sheets & 0,000 \\
\hline Posttest-Feedback Sheets & \\
\hline
\end{tabular}

Based on table 4 by using the Wilcoxon test showing that the value of pretest to posttest group Balik sheet has a value $p=0.000(<0,05)$ which means there is a significant difference between the scores pre-test and post-test in the Feedback Sheet group.

The results of the study are in line with research conducted by [4] which shows that there is an increase in family knowledge after being given health education with a flipchart in the experimental group. Audiovisual media provide stimulation through the eyes and ears. Attractive audio-visual media can attract individual attention and the message conveyed will be easier to understand. The organ which transmits the most knowledge is the eye. Approximately $75-87 \%$ of human knowledge is acquired or transmitted through the eye, and another $13-25 \%$ is channeled through other senses. Therefore, in the application of making media, it is recommended to use more visual and audiovisual tools because it will facilitate the way of delivering and receiving information from the public [5]

In other words, flipchart media can be the method of choice for increasing respondents' knowledge, it is proven that it can improve the knowledge score of young women about menstrual pain (dysmenorrhea), where this increase is a result of providing health education with audiovisual media. Thus the audio visual media as an effective health education media is used to improve respondent's knowledge for the better.

\section{CONCLUSION.}

The leaflet method and the flipchart method both have effects on the student's knowledge score about menstrual pain (dysmenorrhea). From the results of this study it was suggested to Anyer I State High School to apply the leaflet method and the flipchart method in 
providing health education specifically about menstrual pain (dysmenorrhea).

\section{REFERENCES}

[1] S. Hailemeskel, A. Demissie, dan N. Assefa, "Primary dysmenorrhea magnitude, associated risk factors, and its effect on academic performance: Evidence from female university students in Ethiopia," Int. J. Womens. Health, vol. 8, hal. 489496, 2016.

[2] M. Armour, C. A. Smith, K. A. Steel, dan F. Macmillan, "The effectiveness of self-care and lifestyle interventions in primary dysmenorrhea: a systematic review and meta-analysis," $B M C$ Complement. Altern. Med., vol. 19, no. 1, hal. 1-16, 2019.

[3] Soekidjo Notoatmodjo, "Metodologi penelitian kesehatan," Jakarta: Rineka Cipta, 2012.

[4] M. Y. Dawood, "Clinical Expert Series Primary Dysmenorrhea Advances in Pathogenesis and Management," Obs. Gynecol, vol. 108, no. 2, hal. 428-41, 2006.

[5] H. M. Hm, N. H. Nh, dan A. M. Am, "East African Journal of Health and Biomedical Sciences ( 2019 ) Dysmenorrhea and Associated Factors among Secondary School Students in East Hararghe Zone , Eastern Ethiopia," vol. 3, 2019.

[6] P. Sharlin, H. Sukandar, dan R. Fadil, "Familial Predisposition of Primary Dysmenorrhea among Senior High School Girl Students," Althea Med. J., vol. 2, no. 4, hal. 579-583, 2015.

[7] M. A. Burnett et al., "Prevalence of Primary Dysmenorrhea in Canada," J. Obstet. Gynaecol. Canada, vol. 27, no. 8, hal. 765770, 2005.

[8] H. Hand, The Ups and Down of the Menstural Cycle. Practice. 2010.

[9] L. French, “American Academy For Family Phisicians," Am. Acad. Fam. Phisicians, vol. 71, no. 2, hal. 285-191, 2005.

[10] V. T. Miller, "Diagnosis and initial management of stroke," Compr. Ther., vol. 14, no. 7, hal. 57-65, 1988.

[11] I Gde Manuaba, "Memahami Reproduksi Wanita," Jakarta: Arcan, 2010

[12] A. Baziad, "Endokrinologi ginekologi," in edisi ketiga, Jakarta: Media Aesculapius., 2008.

[13] A. A. of S. Administrators, "Maternity Leave Provisions for Classroom Teachers in Larger School Systems," 1966. 